\title{
Effect of gala apples (Malus domestica Borkh) on lipidemia of hyperlipidemic rats
}

\author{
Efeito da maçã gala (Malus domestica Borkh) na lipidemia de ratos hipercolesterolêmicos
}

\author{
Jocelem Mastrodi SALGADO ${ }^{1 *}$, Fabiana CURTE ${ }^{1}$, Débora Niero MANSI ${ }^{1}$
}

\begin{abstract}
A healthy life style and a balanced diet, associated with a high fruit and vegetable intake, are linked to good health and the prevention of diseases. Apples contain bioactive compounds that help in the prevention and control of hyperlipidemia. One of the Public Health concerns in Brazil is to reduce cardiovascular diseases. Therefore, the objective of this work was to analyze the chemical composition of Gala apples and to study the effect of their consumption on weight gain, food intake, serum levels of total cholesterol, HDL-C, LDL-C, triglycerides, hepatic cholesterol and fecal cholesterol in male albino Wistar rats fed a hypercholesterolemic diet. Six animals were utilized for each treatment (control, 5, 15 and 25\% apple diet), during 30 and 60 days. This study showed that one apple ( $200 \mathrm{~g}$ ) can provide $14.5 \%$ of recommended total fiber and $55 \%$ of recommended vitamin C, besides supplying considerable quantities of phenolic compounds $\left(0.38 \mathrm{~g} .100 \mathrm{~g}^{-1}\right)$ and tannins $\left(0.16 \mathrm{~g} .100 \mathrm{~g}^{-1}\right)$. All animals showed a non-significant reduction in their weight gain and food intake with an increase in the concentration of apple in the diets. At the end of 30 days, all of the diets provided a significant reduction in the levels of triglycerides compared to the control group. The 15 and 25\% apple diets showed significant reductions in the serum levels of total cholesterol and LDL-C and an increase in the level of fecal cholesterol in relation to the control group. The $25 \%$ apple diet provided a significant reduction in the hepatic cholesterol levels compared to the control group. After 60 days, the serum levels of total cholesterol, LDL-C, HDL-C and triglycerides in rats fed with 5,15 and $25 \%$ apple diets were similar to the control group. This probably happened due to a revertion of the process. These results show the importance of Gala apples in the control of hyperlipidemia in rats. A diet rich in vegetables and fruits, including apples, associated to a healthy life style, over time, could prevent or reduce the risk of heart disease.
\end{abstract}

Keywords: cholesterol; apple; rats.

\section{Resumo}

Um estilo de vida saudável e uma dieta balanceada, associados com uma alta ingestão de frutas e vegetais estão ligados também à boa saúde e a prevenção de doenças. Maçãs contêm compostos bioativos que ajudam à prevenção e controle da hiperlipidemia. Uma das preocupações da Saúde Pública no Brasil é reduzir as doenças cardiovasculares. Assim, o objetivo deste trabalho foi analisar a composição química da maçã Gala e estudar o efeito do seu consumo no ganho de peso, comida ingerida, níveis sanguíneos de colesterol total, HDL-C, LDL-C, triglicérides, colesterol hepático e colesterol fecal em ratos albinos Wistar, alimentados com uma dieta hipercolesterolêmica. Foram utilizados seis animais para cada tratamento (controle, 5, 15, e 25\% dieta de maçã), durante 30 e 60 dias. Este estudo mostrou que uma maçã (200 g) pode contribuir com $14,5 \%$ do total de fibras e $55 \%$ da vitamina C recomendados, além de suprir consideráveis quantidades de produtos fenólicos $\left(0,38 \mathrm{~g} .100 \mathrm{~g}^{-1}\right)$ e taninos $\left(0,16 \mathrm{~g} \cdot 100 \mathrm{~g}^{-1}\right)$. Todos os animais mostraram uma redução não significativa no ganho de peso e ingestão de comida com o aumento na quantidade de maçã na sua dieta. Ao final de 30 dias, todas as dietas resultaram em uma redução significativa de triglicérides comparados ao grupo controle. As dietas de 15 e $25 \%$ mostraram redução significativa nos níveis séricos de colesterol total e LDL-C e um aumento nos níveis fecais de colesterol em relação ao grupo controle. A dieta de $25 \%$ de maçã resultou em uma significativa redução dos níveis de colesterol hepático comparados com o grupo controle. Depois de 60 dias, os níveis séricos de colesterol total, LDL-C, HDL-C e triglicérides em ratos alimentados com 5, 15 e 25\% de dieta de maçã eram similares ao grupo controle. Isto, provavelmente foi devido a uma reversão do processo. Estes resultados mostram a importância da maçã Gala no controle da hiperlipidemia em ratos. A dieta rica em vegetais e frutas, incluindo maçãs, e associada a um estilo de vida saudável, com o tempo pode prevenir e reduzir o risco de doenças cardíacas.

Palavras-chave: colesterol; maçã; ratos.

\section{Introduction}

Diseases of the cardiovascular system are the number one cause of deaths in Brazil, possibly accounting for as many as one third of all deaths. This corresponds to a considerable loss of lives and represents a significant financial expense for the country. To change this picture it is necessary to strongly focus on reducing the risk factors, of which hypercholesterolemia is considered one of the main causes (CARAMELLI, 2002; ROSS, 1999).
The control of cardiovascular diseases in patients with hypercholesterolemia can be done via the use of medication, physical activity and through nutritional therapy. Nutrition is extremely important and should always be considered when determining the risk for cardiovascular diseases (MAZUR et al., 1998; SANTOS, 2001).

Recebido para publicação em 14/6/2007

Aceito para publicação em 16/7/2007 (002603)

Departamento de Agroindústria, Alimentos e Nutrição, Escola Superior de Agricultura "Luiz de Queiroz" - ESALQ, Universidade de São Paulo - USP, CP 9, Piracicaba - SP, Brasil, E-mail: jmsalgad@esalq.usp.br

${ }^{*}$ A quem a correspondência deve ser enviada 
Several studies have shown the beneficial effects of the consumption of fruits and vegetables on reducing the risks of developing and even reducing cardiovascular diseases (BAZZANO et al., 2002; HU, 2003; LAMPE, 1999; LIU et al., 2000; PANAGIOTAKOS, 2003). However, there are not many researches studying the use of apples in this area, and some of them include their antioxidant compounds (APRIKIAN, et al., 2003; BOYER; LIU, 2004; LEJA; MARECZEK; BEN, 2003; LEONTOWICZ et al., 2001; LEONTOWICZ et al., 2003; OGINO et al., 2007; SEMBRIES et al., 2006; VIDAL et al., 2005).

The compounds most commonly found in apple peels, among others, are procyanins, catechin, epicatechin and quercetin conjugates (ESCARPA; GONZALES, 1998). Because the apple peels contain more antioxidant compounds, especially quercetin, apple peels may have higher antioxidant activity and bioactivity than the apple flesh. Research showed that apples without the peels had less antioxidant activity than apples with the peels (EBERHARDT; LEE; LIU, 2000). More recent work has shown that apples with the peels contain anywhere from two to six times more phenolic compounds than that in the flesh, and there are two to three times more flavonoids in the peels when compared to the flesh. The antioxidant activity of these peels was also much greater when compared to the flesh (WOLFE; LIU, 2003). This work is supported by Leontowicz et al. (2003), who found that rats consuming apple peels showed greater inhibition of lipid peroxidation than rats fed apple flesh.

Apples are considered the preferred fruit by consumers that prioritize practicality (HARKER; GUNSON; JAEGER, 2003) and, among the various varieties, Gala is responsible for $48 \%$ of the national production (PETRI, 2003). However, the consumption of apples in Brazil is relatively low, at only 7.5\%, when compared to other fruits (IBGE, 2006). Currently, an increased apple production and a low national demand have combined caused a crisis in this sector, with the saturation of the market. In the case of the Brazilian market, one way to solve this crisis would be to increase apple consumption (FNP, 2002). A tactic for increasing apple consumption would be to conduct studies with the fruit to substantiate their beneficial effects for humans, thus establishing functional health claims that could be used to promote the fruit to consumers.

The objective of this study was to analyze the chemical composition of dried apple flour (DAF), Gala variety, and to evaluate the effects of its consumption on the blood level concentrations of total cholesterol, HDL-C, LDL-C, triglycerides, hepatic and excreted cholesterol. In addition, the effect of DAF consumption on weight gain of hypercholesterolemic rats was analyzed.

\section{Materials and methods}

\subsection{Raw material - apple}

Ripe apples (Gala variety) obtained at a local market in Piracicaba, SP, Brazil, were used. The apples were surface disinfected with a chlorinated water solution (100 ppm). One kg of apples was sliced and $100 \mathrm{~mL}$ of a $1 \%$ ascorbic acid solution was mixed with the apple slices to avoid enzymatic darkening. The slices were placed in trays and dried in a forced air-circulating incubator at 55 and $60{ }^{\circ} \mathrm{C}$ for 48 hours. The dried samples were ground to a fine flour using a TE 045 blender (Marconi, Piracicaba, SP, Brazil), stored in clear polyethylene bags and kept at $4{ }^{\circ} \mathrm{C}$ prior to use.

\subsection{Chemical analyses of the DAF}

Dry matter, proteins, lipids and ash content of the DAF were determined according to the methodology described by the AOAC (1995). Dry matter was obtained by drying the samples in an incubator at $105{ }^{\circ} \mathrm{C}$ until constant weight was reached, and moisture was estimated by difference. The determination of nitrogen was conducted using the micro Kjeldahl method and protein content was obtained by multiplying total nitrogen by the conversion factor 6.25. Lipid content was determined with the Soxhlet extractor using ethyl ester as solvent. Ash was obtained by incinerating the samples in a laboratory oven, at $600{ }^{\circ} \mathrm{C}$, for 4 hours. Soluble and insoluble fiber contents were evaluated by the method proposed by ASP et al. (1983). Total phenolic compounds were determined by the methodology described by Swain and Hillis (SWAIN; HILLIS, 1959), while tannins were analyzed according to Price et al. (1978). Vitamin C content was determined using fresh Gala apples, according to Pregnolatto and Pregnolatto (PREGNOLATTO; PREGNOLATTO, 1985).

Carbohydrate values were derived empirically after subtracting the other components (AOAC, 1995), and mineral contents were determined according to Sarruge and Haag (SARRUGE; HAAG, 1974).

\subsection{Biological assay}

\section{Preparation of the diets}

The diets were prepared according to Reeves, Nielsen and Fahey (1993) and were supplemented with pork lard (206 mg cholesterol.100 $\mathrm{g}^{-1}$ ) (PREGNOLATTO; PREGNOLATTO, 1985).

The following diets were used for the biological assay: control, 5, 15 and 25\% of dried apple flour (DAF). Table 1 depicts the composition of the diets evaluated in the experiment.

\section{Animals}

Three to 4-month-old adult male albino Wistar rats (Rattus norvegicus var. albinos) weighing 230 to $250 \mathrm{~g}$ were used for the biological assay.

During the pre-experimental stage, the animals were kept grouped in cages ( 6 rats per cage), at 22 to $23^{\circ} \mathrm{C}$, with a 12 hours light cycle, and received a commercial Purina ration with water ad libitum until they reached ideal weight. Of these animals, six rats were sacrificed as soon as they reached the desired weight and their blood level concentrations of total cholesterol, LDL-C, HDL-C, triglycerides and hepatic cholesterol were analyzed for comparison parameters (normal levels). Another 54 rats were selected and fed hypercholesterolemic diets. After one week, six animals were sacrificed and designated as the initial control. The remaining 48 animals were divided into four groups with 
Table 1. Composition of the diets (g.100 g $\mathrm{g}^{-1}$ ) with and without (control) dried Gala apple flour (DAF).

\begin{tabular}{|c|c|c|c|c|}
\hline \multirow[t]{2}{*}{ Components } & \multicolumn{4}{|c|}{ Diets } \\
\hline & Control & $5 \%$ DAF ( $5 \mathrm{~g})$ & $15 \%$ DAF (15 g) & $25 \%$ DAF $(25 \mathrm{~g})$ \\
\hline Casein $^{1}$ & 15.0 & 15.0 & 15.0 & 15.0 \\
\hline Dried apple flour ${ }^{2}$ & - & 5.0 & 15.0 & 25.0 \\
\hline Vitamin mixture ${ }^{4}$ & 1.0 & 1.0 & 1.0 & 1.0 \\
\hline Soybean oil ${ }^{5}$ & 3.0 & 3.0 & 3.0 & 3.0 \\
\hline Sucrose $^{8}$ & 10.0 & 10.0 & 10.0 & 10.0 \\
\hline$\alpha$ - Cystine ${ }^{9}$ & 0.3 & 0.3 & 0.3 & 0.3 \\
\hline tert - butylhydroquinone $\mathrm{e}^{10}$ & 0.0014 & 0.0014 & 0.0014 & 0.0014 \\
\hline Starch $^{11}$ & \multicolumn{4}{|c|}{ To complete $100 \mathrm{~g}$} \\
\hline
\end{tabular}

12 rats each for the following diet treatments: $0 \%$ (control), 5,15 and $25 \%$ of apple flour. For each treatment, six animals were sacrificed at 30 days and the other six at 60 days. These animals were kept in individual cages in the same conditions mentioned above and the collection of their feces and registration of their weight gain and diet consumption were conducted three times a week.

At the end of each period, the animals were sacrificed by cardiac puncture to collect blood and liver samples, which was done after the animals had fasted for 12 hours. The samples were analyzed immediately after collection.

\section{Biochemical analyses: Blood/Liver/Feces}

Blood was collected from sacrificed animals by cardiac puncture through an inclusion in the abdominal and thoracic cavities. Total cholesterol, HDL-C and triglycerides were analyzed by utilizing an enzymatic kit from the Wiener Lab Chemical Industry. The contents of LDL-C were identified by Equation 1, according to Friedewald et al. (1972).

$$
\text { LDL }=\text { Total cholesterol }-\mathrm{HDL}-\frac{\text { Triglycerides }}{5}
$$

Liver samples were taken from the sacrificed animals and prepared according to the method proposed by Haug and Hostmark (1987). Hepatic cholesterol was determined with the same kit mentioned above.

During the experimental period, feces of rats from the initial control group, control, 5, 15 and 25\% DAF treatments were collected and stored over the experimental periods, 30 and 60 days, in individually identified plastic bags and refrigerated. At the end of the experiment, the feces were dried at $105{ }^{\circ} \mathrm{C}$, for 72 hours, and ground for analysis. Excreted cholesterol was determined by the same method conducted for the liver samples.

\section{Statistical analysis}

The statistical program SANEST (Statistic Analysis System), developed by Zonta and Machado, was used to analyze the data. The $F$ test was applied for the analysis of variance and the Tukey test to identify significant differences between means. A $\mathrm{p} \leq 0.05$ significance level was established for the contents of total cholesterol, HDL-C, LDL-C and triglycerides, hepatic and excreted cholesterol.

\section{Results and discussion}

\subsection{Yield}

Laboratory-dried samples of the Gala apples transformed into flour presented a yield of $16.68 \%$, when compared to the fresh apples.

\subsection{Composition}

Results from the composition analyses of proteins, ash, lipids, soluble and insoluble fiber and carbohydrates available in the dried apple flour can be seen in Table 2.

\subsection{Minerals}

Table 3 shows the contents of the following minerals: phosphorus, calcium, potassium, magnesium, sulfur, sodium, copper, iron and zinc.

The values for $\mathrm{Ca}, \mathrm{Cu}, \mathrm{Mg}$ and $\mathrm{Zn}$ found in the apple ash were similar to those reported by Gorinstein (2001) and Philippi (2001), however, the value observed for P in this study disagreed with that cited by Philippi (2001), which could be due to factors such as apple variety, maturation stage, soil conditions, fertilization, irrigation and temperature.

\subsection{Vitamin C/Phenolic compounds/Tannins}

Phenolic compounds (0.38 g.100 g $\left.\mathrm{g}^{-1} \pm 0.0004\right)$ and tannins $\left(0.16 \mathrm{mg} .100 \mathrm{~g}^{-1} \pm 0.0002\right)$ were found in DAF. Vitamin C (25 mg.100 $\mathrm{g}^{-1}$ ) was determined in fresh apples and three repetitions were conducted per analysis. The values found for vitamin $\mathrm{C}$, phenolic compounds and tannins in this study corroborate with others found in literature (COMBS, 1998; LEJA; MARECZEK; BEN, 2003; WILSKA-JESZKA, 1996). 
Apples are a very significant source of flavonoids in the diet in America and Europe, and they are also a good source of antioxidants and phenolic compounds. Apples had the highest portion of free phenolics when compared to other fruits. This means that these compounds are not bound to other compounds in the fruits, and the phenolics may be more available for eventual absorption into the bloodstream (BOYER; LIU, 2004).

Some of these compounds may be absorbed from the intestine and their metabolites may influence lipid metabolism (OGINO et al., 2007).

Several investigations have shown that fruits are a natural source of dietary fiber, trace elements and antioxidant compounds, and that diets rich in fruits positively influenced plasma lipid levels and antioxidant capacities in experiments with laboratory animals (GORINSTEIN et al., 2001; GORINSTEIN et al., 2002; LEONTOWICZ et al., 2001; LEONTOWICZ et al., 2002).

Boyer and Liu (2004) found that the total antioxidant activity of apples with their peel was approximately $83 \mu \mathrm{mol}$ vitamin $C$ equivalents, which means that the antioxidant activity of $100 \mathrm{~g}$ apples is equivalent to about $1500 \mathrm{mg}$ of vitamin C.

Table 2. Composition of Gala apple flour (g.100 g-1 , dry matter basis).

\begin{tabular}{lc}
\hline \multicolumn{1}{c}{ Component $^{*}$} & Mean \pm standard deviation \\
\hline Protein & $3.61 \pm 0.10$ \\
Ash & $1.53 \pm 0.10$ \\
Lipids & $1.55 \pm 0.10$ \\
Insoluble fiber & $2.37 \pm 1.10$ \\
Soluble fiber & $10.03 \pm 1.10$ \\
Available carbohydrates & 80.91 \\
\hline
\end{tabular}

${ }^{*}$ Mean and standard deviation from three repetitions; ${ }^{*}$ Derived empirically after subtracting the other components.

Table 3. Mineral composition (mg.100 $\mathrm{g}^{-1}$ ) of Gala apple flour raw material.

\begin{tabular}{lc}
\hline \multicolumn{1}{c}{ Component $^{*}$} & Mean \pm standard deviation \\
\hline Phosphorus $(\mathrm{P})$ & $16.89 \pm 0.20$ \\
Calcium $(\mathrm{Ca})$ & $4.22 \pm 0.80$ \\
Potassium $(\mathrm{K})$ & $158.93 \pm 6.80$ \\
Magnesium $(\mathrm{Mg})$ & $5.24 \pm 0.40$ \\
Sulfur $(\mathrm{S})$ & $5.24 \pm 0.30$ \\
Sodium $(\mathrm{Na})$ & $38.84 \pm 0.01$ \\
Copper $(\mathrm{Cu})$ & $0.09 \pm 0.00$ \\
Iron $(\mathrm{Fe})$ & $0.41 \pm 0.07$ \\
Zinc $(\mathrm{Zn})$ & $0.04 \pm 0.01$ \\
\hline
\end{tabular}

${ }^{*}$ Mean and standard deviation from three repetitions.

\subsection{Biological assay}

\section{Diet consumption and weight gain}

Data shown in Table 4 indicate that there were no significant differences in the consumption or weight gain of animals fed diets with increased concentrations of apple flour.

The increase in the concentration of DAF is correlated with a greater fiber content, mainly the soluble fraction. Marlett et al. (2002) and Plaami (1997) stated that soluble fiber develops high viscosity, which is frequently associated with the effects of reducing gastric emptiness, thus promoting a greater fulfillment sensation. Therefore, in our study, diet consumption did not increase with the increase of apple flour concentration.

Obesity has become a serious public health issue, due to the costs associated to this problem. This could be attenuated or reverted by implementing nutritional education programs in schools and through nutritional re-education of adults with the introduction of healthier food such as fruits and vegetables. Apples, as shown in this study, could be an excellent alternative, due to their availability and low cost.

\section{Total cholesterol}

The total cholesterol level in the normal group was $65.26 \pm 1.50 \mathrm{mg} \cdot \mathrm{dL}^{-1}$ and the values found for the initial control group of animals fed a hypercholesterolemic diet for a week was $93.34 \pm 0.90 \mathrm{mg} \cdot \mathrm{dL}^{-1}$. Figure 1 illustrates the serum levels of total cholesterol found in the biological assays.

Diets with 15 and 25\% DAF at 30 days caused significant reductions of 19.30 and $20.70 \%$, respectively, in the levels of total cholesterol, when compared to the control. At 60 days, there was a slight reduction in total cholesterol that varied between 2 and $3 \%$ for the 15 and 25\% diets, respectively, when compared to the control.

Several studies have shown that soluble fiber favors the reduction of the levels of blood cholesterol. Camire and Dougherty (2003) and Savaiano (2000) stated that the reduction of plasmatic cholesterol in rats was caused by soluble fibers that linked cholesterol irreversibly to bile acids and carried them to the feces, thus hindering their absorption by the liver. Simultaneously, these fibers favored the synthesis of bile salts by the liver, stimulating the utilization of blood cholesterol.

Another important physiological effect promoted by soluble fiber is the formation of viscous structures that reduce the absorption of compounds such as lipids and cholesterol in the

Table 4. Mean values for diet consumption (g) and weight gain (g) of Wistar rats at 30 and 60 days.

\begin{tabular}{lccccc}
\hline \multicolumn{1}{c}{ Diets } & \multicolumn{2}{c}{ At 30 days } & & \multicolumn{2}{c}{ At 60 days } \\
\cline { 2 - 5 } & Weight gain $(\mathrm{g})$ & Diet consumption $(\mathrm{g})$ & & Weight gain $(\mathrm{g})$ & Diet consumption $(\mathrm{g})$ \\
\hline Control $^{1}$ & $97.10^{2} \pm 2.00^{\mathrm{a} 3}$ & $459.80 \pm 6.80^{\mathrm{a}}$ & & $216.80 \pm 13.80^{\mathrm{a}}$ & $922.80 \pm 21.90^{\mathrm{a}}$ \\
$5 \%$ dried apple flour $^{\mathrm{a}}$ & $96.20 \pm 2.00^{\mathrm{a}}$ & $458.60 \pm 4.60^{\mathrm{a}}$ & & $210.90 \pm 9.80^{\mathrm{a}}$ & $918.40 \pm 17.00^{\mathrm{a}}$ \\
$15 \%$ dried apple flour & $95.70 \pm 2.40^{\mathrm{a}}$ & $457.60 \pm 8.00^{\mathrm{a}}$ & & $209.80 \pm 7.80^{\mathrm{a}}$ & $910.00 \pm 19.90^{\mathrm{a}}$ \\
$25 \%$ dried apple flour & $95.40 \pm 1.50^{\mathrm{a}}$ & $456.20 \pm 9.10^{\mathrm{a}}$ & & $209.00 \pm 1.40^{\mathrm{a}}$ & $904.50 \pm 28.40^{\mathrm{a}}$ \\
\hline
\end{tabular}

${ }^{1}$ Without fiber; ${ }^{2}$ Mean \pm standard deviation from six Wistar rats per treatment; ${ }^{3}$ Means with different letters in columns differ statistically at $\mathrm{p} \leq 0.05$. 
small intestine (CORRÊA, 2002; DE ANGELIS, 2001; SWAIN; HILLIS, 1959).

The association of pectin with polyphenols in apple extract effectively lowered the concentrations of cholesterol in the circulation, as shown in previous experiments using whole fruit extracts (APRIKIAN et al., 2003; SABLE-AMPLIS; SICART; BLUTHE, 1983; LEONTOWICZ et al., 2001).

Another interesting feature is that pectin stimulated steroid excretion through a greater elimination of cholesterol, with a concomitant reduced excretion of bile acid in the feces. This feature is rather unusual because the cholesterol-lowering effects of fiber are frequently considered to indicate the accelerated oxidation of cholesterol, through induction of liver cholesterol in response to interactions of bile acids with dietary constituents (APRIKIAN et al., 2003).

\section{$H D L-C$}

Figure 2 depicts the effect of the experimental diets on the serum levels of HDL-C at 30 and 60 days of the treatments.

The diets with 5 and 15\% DAF showed a slight increase of 0.9 and $1.9 \%$, respectively, at 30 days, while the diet with $25 \%$ DAF caused an increase of $7 \%$ in the levels of HDL-C when compared to the control in the 30 days of experiment. Figure 2 clearly illustrates the effects of the $25 \%$ DAF diet on the increase of HDL-C. This result is in accordance with Aprikian et al. (2002), who found that when cholesterol-fed rats were supplemented with apples, there was a significant drop in plasma cholesterol and an increase in high-density lipoproteins (HDL). More studies investigated these parameters using apples, pears and peaches, with apples having the greatest effect (BOBEK; OZDÍN; HROMADOVÁ, 1998; LEONTOWICZ et al., 2003). Apples contained more phenolic compounds, suggesting that perhaps the phenolics in apples contribute to this effect (LEONTOWICZ et al., 2002).

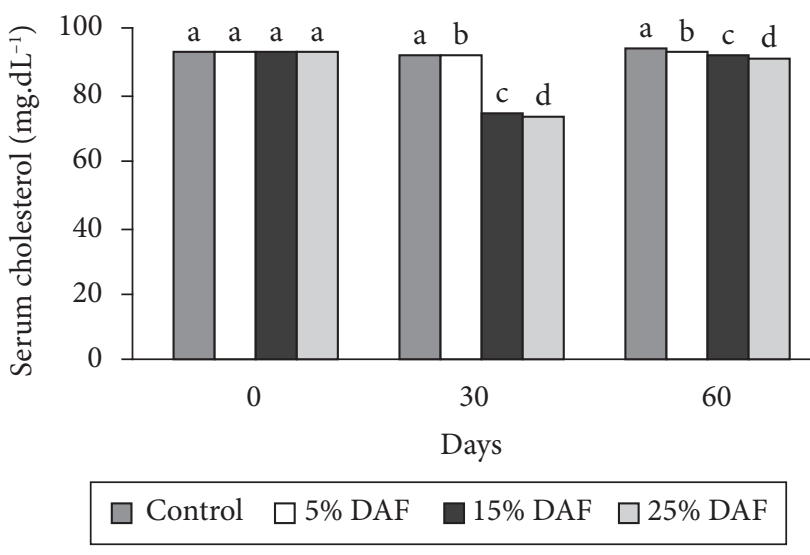

Figure 1. Serum levels of cholesterol $\left(\mathrm{mg}^{\mathrm{d}} \mathrm{dL}^{-1}\right)$ in Wistar male albino rats fed Gala dried apple flour (DAF) for a 60-day period. Where: Control $=15 \%$ casein diet; $5 \% \mathrm{DAF}=5 \%$ of apple flour; $15 \%$ $\mathrm{DAF}=15 \%$ of apple flour; $25 \% \mathrm{DAF}=25 \%$ of apple flour; and Different letters show a significant statistic diference $(\mathrm{p}<0.05)$.
$L D L-C$

Figure 3 shows the effect of the experimental diets on the serum levels of LDL-C at 30 and 60 days of the treatments.

Animals that were fed the 15 and 25\% DAF rations showed significant reductions, 29.60 and $32.30 \%$, respectively, in their levels of LDL-C at 30 days, when compared to the control group.

Diets with 15 and 25\% DAF promoted significant reductions in the levels of total cholesterol and LDL-C. This is important since studies have shown that the reduction of total cholesterol and LDL-C represents an efficient measure to lower cardiovascular mortality associated to patients with cardiovascular disease or to prevent the onset of the disease (LIU et al., 2000; MAGALHÃES; CHAGAS; LUZ, 2002).

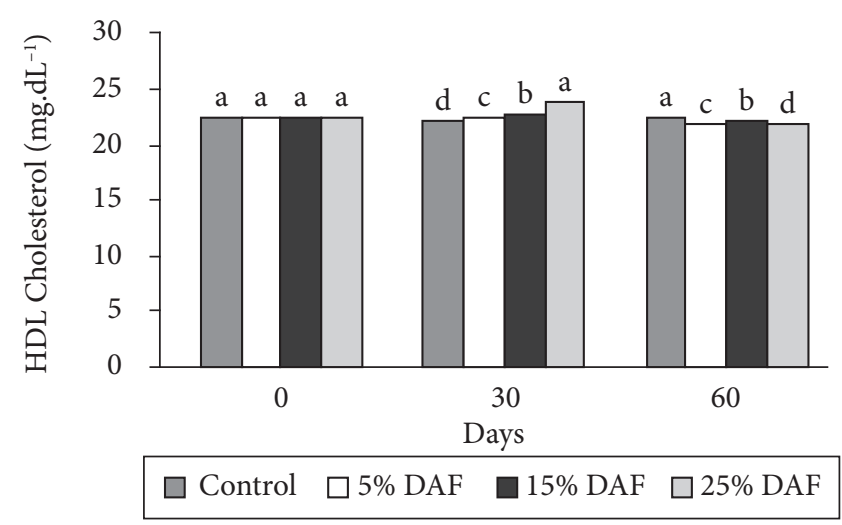

Figure 2. Serum levels of HDL-C (mg.dL $\left.{ }^{-1}\right)$ in Wistar male albino rats fed Gala dried apple flour (DAF) for a 60-day period. Where: Control $=15 \%$ casein diet; $5 \%$ DAF $=5 \%$ of apple flour; $15 \%$ DAF $=15 \%$ of apple flour; $25 \%$ DAF $=25 \%$ of apple flour; and Different letters show a significant statistic diference $(\mathrm{p}<0.05)$.

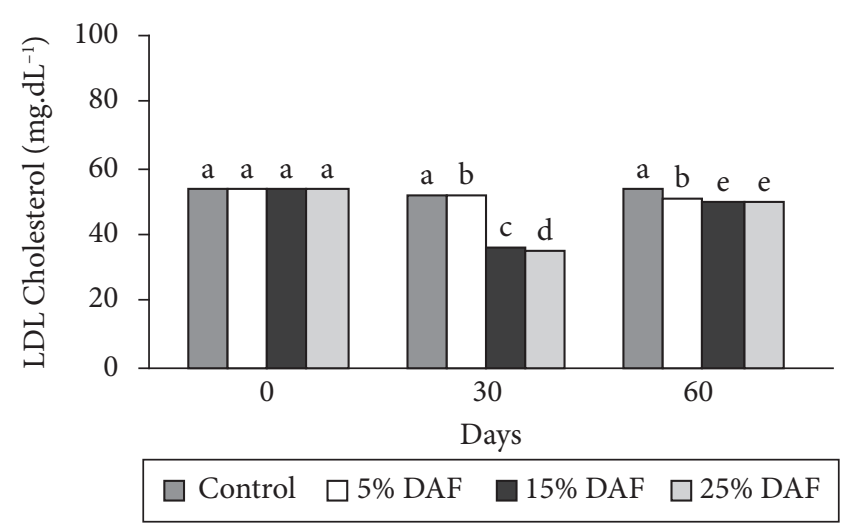

Figure 3. Serum levels of LDL-C (mg.dL $\left.{ }^{-1}\right)$ in Wistar male albino rats fed Gala dried apple flour (DAF) for a 60-day period. Where: Control $=15 \%$ casein diet; $5 \%$ DAF $=5 \%$ of apple flour; $15 \%$ DAF $=15 \%$ of apple flour; $25 \%$ DAF $=25 \%$ of apple flour; and Different letters show a significant statistic diference $(\mathrm{p}<0.05)$. 
Although the hypocholesterolemic mechanisms of dietary fiber are well known and reported, the present study did not show that these effects were the result only of the fibers, since apples also have other bioactive compounds. These bioactive compounds can directly work to reduce the total and fractioned cholesterol and have antioxidant capacities that hinder the formation of oxidized LDL-C, which is a precursor of arteriosclerosis (LUZ; CESENA, 2001).

\section{Triglycerides}

All diets with added DAF significantly reduced the serum levels of triglycerides at 30-days. Figure 4 shows that animals fed diets supplemented with 5 and 15\% DAF showed a reduction of 5 and $15 \%$ in triglyceride levels, respectively. The diet with $25 \%$ DAF caused a reduction of $21.50 \%$ in triglyceride levels, when compared to the control.

\section{Hepatic cholesterol}

As shown in Figure 5, all animals fed diets with 5, 15 and 25\% DAF had a reduction in their hepatic cholesterol of $12,10.30$ and $14.20 \%$, respectively, when compared to animals from the control group.

These results corroborate with those obtained by Aprikian et al. (2001) and Leontowicz et al. (2001), who found that rats fed $15 \%$ apple flour for 21 days had a reduction of $9 \%$ in their hepatic cholesterol levels.

The reduction of hepatic cholesterol observed in animals that had a diet with $25 \%$ DAF could be due to the high concentration of dietary fiber, which has been shown to promote a reduction in the absorption of bile salts by the liver that reduced cholesterol levels. Cholesterol stored in the liver is a substrate for the synthesis of new bile acids that are lost in the feces (CAMIRE; DOUGHERTY, 2003; ELHARDALLOU, 1992; SWAIN; HILLIS, 1959).

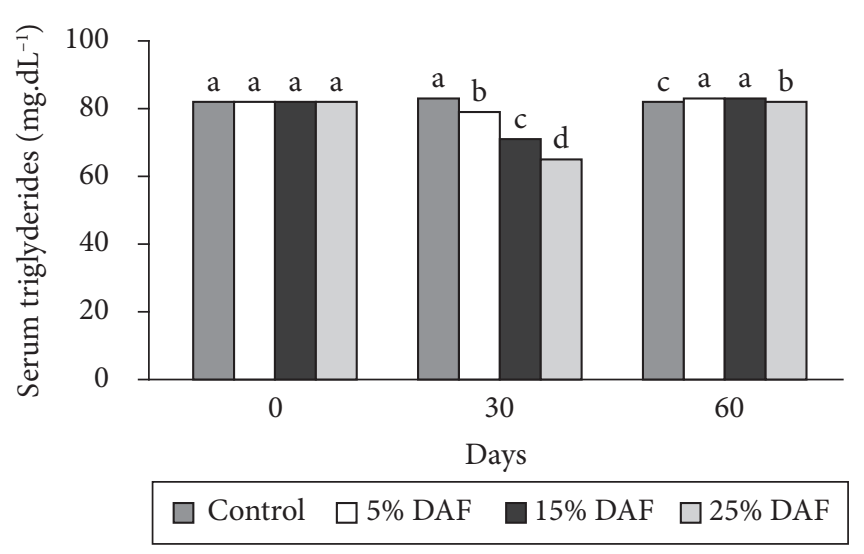

Figure 4. Serum levels of triglycerides $\left(\mathrm{mg} \cdot \mathrm{dL}^{-1}\right)$ in Wistar male albino rats fed Gala dried apple flour (DAF) for a 60 -day period. Where: Control $=15 \%$ casein diet; $5 \%$ DAF $=5 \%$ of apple flour; $15 \%$ DAF $=15 \%$ of apple flour; $25 \% \mathrm{DAF}=25 \%$ of apple flour; and Different letters show a significant statistic diference $(\mathrm{p}<0.05)$
Recently, it has been suggested that fermentation products derived from soluble fiber by anaerobic bacteria present in the intestine could inhibit the synthesis of cholesterol in the liver. This could cause the cholesterol stored in this organ to be used for the synthesis of bile salts, as well as in the composition of cellular membranes and hormones (CORRÊA, 2002).

\section{Excreted cholesterol}

The amount of excreted cholesterol found for the initial control group was $89.53 \pm 0.10 \mathrm{mg} \cdot \mathrm{dL}^{-1}$ (Figure 6), which was similar to that observed for the control group at 30 and 60 days.

At 30 days, there was an increase in the level of excreted cholesterol of $3.40,4.80$ and $4.90 \%$, respectively, for the

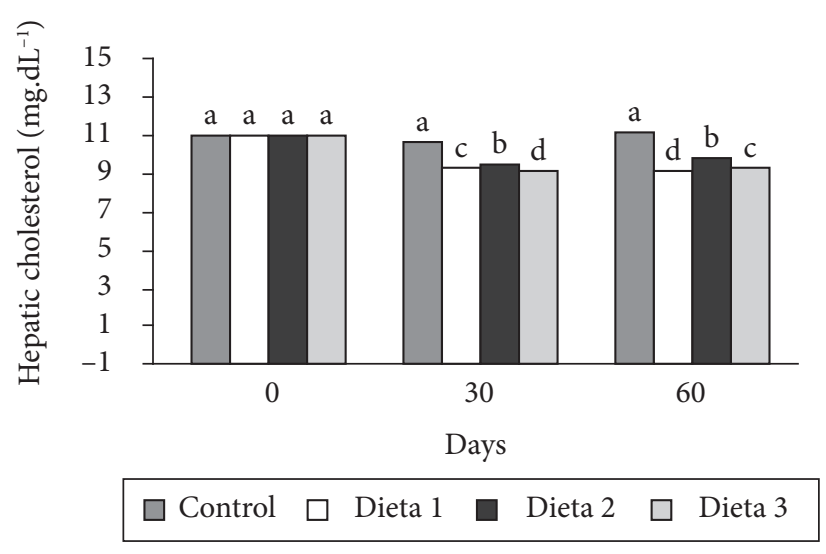

Figure 5. Serum levels of hepatic cholesterol $\left(\mathrm{mg}^{\mathrm{d}} \mathrm{dL}^{-1}\right)$ in Wistar male albino rats fed Gala dried apple flour (DAF) for a 60-day period. Where: Control $=15 \%$ casein diet; $5 \%$ DAF $=5 \%$ of apple flour; $15 \%$ $\mathrm{DAF}=15 \%$ of apple flour; $25 \% \mathrm{DAF}=25 \%$ of apple flour. and Different letters show a significant statistic diference $(\mathrm{p}<0.05)$.

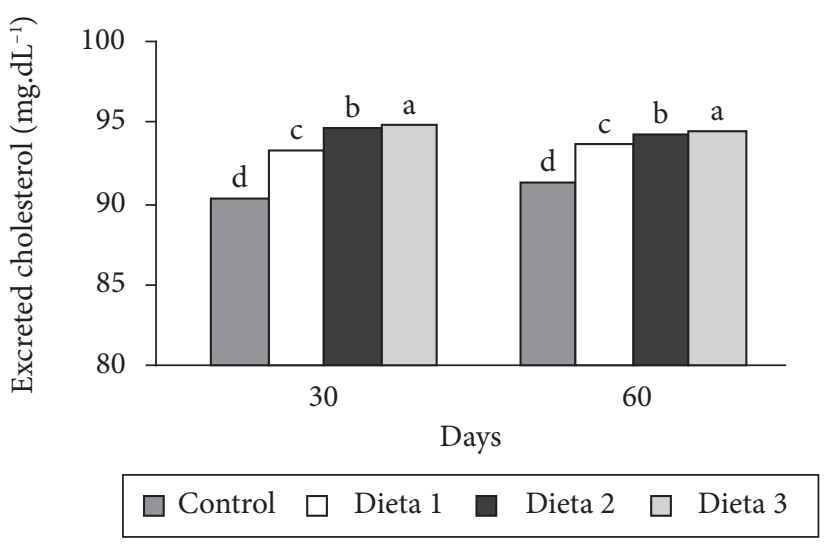

Figure 6. Serum levels of excreted cholesterol $\left(\mathrm{mg} \cdot \mathrm{dL}^{-1}\right)$ in Wistar male albino rats fed Gala dried apple flour (DAF) for a 60-day period. Where: Control $=15 \%$ casein diet; $5 \% \mathrm{DAF}=5 \%$ of apple flour; $15 \%$ $\mathrm{DAF}=15 \%$ of apple flour; $25 \% \mathrm{DAF}=25 \%$ of apple flour; and Different letters show a significant statistic diference $(\mathrm{p}<0,05)$. 
5, 15 and 25\% DAF treatments. At 60 days, the percentage of excreted cholesterol was similar for all the DAF diets. Aprikian et al. (2001) also found an increase in excreted cholesterol in rats, although the values found in this study were higher.

The 15 and 25\% DAF concentrations were efficient to increase the amount of excreted cholesterol. These supplements led to a reduction of blood and liver cholesterol, since soluble fibers have properties that hinder the absorption of nutrients and cholesterol, thus causing a higher level of cholesterol in the feces (DE ANGELIS, 2001; MARCIL et al., 2002).

Another important aspect that can help increase the amount of excreted cholesterol and reduce hepatic cholesterol, is that dietary fiber has the capacity to irreversibly bind to bile acids and thus excrete them with the feces (COLLI; SARDINHA; FILISETTI, 2002; SWAIN; HILLIS, 1959).

\section{Conclusions}

The apple cultivar Gala is an excellent source of dietary fiber and antioxidant compounds.

Increased amounts of dried apple flour in the diets tested did not show an effective reducion of weight gain and diet consumption in rats.

Diets with 15 and $25 \%$ dried apple flour were effective in reducing total cholesterol, LDL-C and triglycerides, and in increasing excreted cholesterol in rats when fed for 30 days.

Diets with 25\% dried apple flour increased the content of HDL-C and decreased hepatic cholesterol.

There is an association between the polyphenolic compounds found in apples and a wide variety of effects that may help prevent chronic disease. This supports the hypothesis that it is the phytochemicals found in apples that impart health benefits.

Based on these results, it is recommended that dried apple flour be included in industrial foods with the purpose of increasing the consumption of compounds beneficial to health.

\section{References}

AOAC. Association Official Analytical Chemists. Official methods of analysis. 16. ed. Washington: AOAC, 1995. $1018 \mathrm{p}$.

APRIKIAN, O. et al. Apple favourably affects parameters of cholesterol metabolism and of anti-oxidative protection in cholesterol fed rats. Food Chemistry, v. 75, n. 4, p. 445-452, 2001.

APRIKIAN, O. et al. Lyophilized apple counteracts the development of hypercholesterolemia, oxidative stress, and renal dysfunction in obese Zucker rats. The Journal of Nutrition, Bethesda, MD, USA, v. 132, n. 7, p. 1969-1976, July 2002.

APRIKIAN, O. et al. Apple Pectin and a Polyphenol-Rich Apple Concentrate Are More Effective Toghether Than Separately on Cecal Fermentations and Plasma Lipids in Rats. The Journal of Nutrition, Bethesda, MD, USA, v. 133, n. 6, p. 1860-1865, 2003.

ASP, N. G. et al. Rapid enzymatic assay of insoluble and soluble dietary fiber. Journal of Agricultural Food Chemistry, Washington, v. 31, n. 3, p. 476-482, May 1983.
BAZZANO, L. A. et al. Fruit and vegetable intake and risk of cardiovascular disease in US adults: the first National Health and [6] Nutrition Examination Survey Epidemiologic Follow-up Study. The American Journal of Clinical Nutrition, v. 76, n. 1, p. 93-99, July 2002.

BOBEK, P.; OZDÍN, L.; HROMADOVÁ, M. The effect of dried tomato, grape and apple pomace on the cholesterol metabolism and antioxidative enzymatic system in rats with hypercholesterolemia. Nahrung, v. 42, n. 5, p. 317-320, 1998.

BOYER, J.; LIU, R. H. Apple phytochemicals and their health benefits. Nutrition Journal, New York, v. 3, n. 5, p. 1-15, 2004.

CAMIRE, M. E.; DOUGHERTY, M. P. Raisin dietary fiber composition and in vitro bile acid binding. Journal of Agricultural and Food Chemistry, Washington, v. 51, n. 3, p. 834-837, 2003.

CARAMELLI, B. Avaliação do risco cardiovascular. In: BRASIL. Ministério da Saúde; Universidade de São Paulo; Instituto para o Desenvolvimento da Saúde. Manual de condutas médicas. Brasília, 2002. 490 p. (Série A. Normas e Manuais Técnicos, 143).

COLli, C.; SARDINHA, F.; FILISETTI, T. M. C. C. Alimentos funcionais. In: SCHOR, N. (Coord.).; CUPPARI, L. (Ed.). Guia de nutrição: nutrição clínica no adulto. São Paulo: Manole, 2002. cap. 4 , p. 55-70.

COMBS, G. F. Jr. The vitamins fundamental aspects in nutrition and health. 2. ed. San Diego: Academic Press, 1998. 618 p.

CORREAA, A. D. Fibras na prevenção de doenças. Lavras: UFLA/ FAEPE, 2002. 43 p.

DE ANGELIS, R. C. Importância de alimentos vegetais na proteção da saúde: fisiologia da nutrição protetora e preventiva de enfermidades degenerativas. São Paulo: Atheneu, 2001. 295 p.

EBERHARDT, M.; LEE, C.; LIU, R. H. Antioxidant activity of fresh apples. Nature, New York, v. 405, n. 6789, p. 903-904, 2000.

ELHARDALLOU, S. B. The bile acids binding of the fibre-rich fractions of three starchy legumes. Plant Food for Human Nutrition, Berlin, v. 42, n. 3, p. 207-218, 1992.

ESCARPA, A.; GONZALES, M. High-performance liquid chromatography with diode-array detection fot the performance of phenolic compounds in peel and pulp from different apple varieties. Journal of Chromatography A: Including Electrophoresis, Mass Spectrometry and other Separation and Detection Methods, v. 823 , p. 331-337, 1998.

FNP - Consultoria \& Comércio. Agrianual 2002: anuário da agricultura brasileira. São Paulo, 2002. p. 370-380. (Maçã).

FRIEDEWALD, W. T.; LEVY, R. I.; FREDRICKSON, D. S. Estimation of the concentration of low-density lipoprotein cholesterol in plasma, without use of the preparative ultracentrifuge. Clinical Chemistry, v. 18, n. 6, p. 499-502, June 1972.

GORINSTEIN, S. et al. Comparative content of some phytochemicals in Spanish apples, peaches end pears. Journal of Science Food and Agriculture, v. 86, p. 1166-1170, 2002.

GORINSTEIN, S. et al. Comparative contents of dietary fiber, total phenolics, and minerals in persimmons and apples. Journal of Agricultural Food Chemistry, Washington, v. 49, n. 2, p. 952-957, Feb. 2001.

GORINSTEIN, S. et al. Comparison of some biochemical characteristics of different citrus fruits. Food Chemistry, v. 74, n. 3, p. 309-315, 2001.

HARKER, F. R.; GUNSON, F. A.; JAEGER, S. R. The case for fruit quality: an interpretative review of consumer attitudes, and preferences for apples. Postharvest Biology and Technology, v. 28, n. 3, p. 333-347, 2003. 
HAUG, A.; HOSTMARK, A. T. Lipoprotein lipases, lipoproteins and tissue lipids in rats fed fish oil or coconut oil. The Journal of Nutrition, v. 117, n. 6, p. 1011-1017, 1987.

HU, F. B. Plant-based foods and prevention of cardiovascular disease: an overview. The American Journal of Clinical Nutrition, v. 78, n. 3, p. 544-551, Sep. 2003. Supplement.

IBGE - Instituto Brasileiro de Geografia e Estatística. Pesquisa de orçamentos familiares, 2003. Disponível em: <http//:www.sidra. ibge.gov.br,2003>. Acesso em: 09 nov. 2003

LAMPE, J. Health effects of vegetable and fruit: assessing mechanisms of action in human experimental studies. The American Journal of Clinical Nutrition, v. 70, n. 3, p. 475-490, Sep. 1999. Supplement.

LEJA, M.; MARECZEK, A.; BEN, J. Antioxidant properties of two apple cultivars during long-term storage. Food Chemistry, v. 80, n. 3, p. 303-307, 2003.

LEONTOWICZ, M. et al. Sugar beet pulp and apple pomace dietary fibers improve lipid metabolism in rats fed cholesterol. Food Chemistry, v. 72, n. 1, p. 73-78, 2001.

LEONTOWICZ, H. et al. Comparative content of some bioactive compounds in apples, peaches and pears and their influence on lipids and antioxidant capacity in rats. Journal of Nutrition Biochemistry, v. 13, n. 10, p. 603-610, Oct. 2002.

LEONTOWICZ, H. et al. Apple and Pear and Pulp and Their Influence on Plasma Lipids and Antioxidant Potentials in Rats fed CholesterolContaining Diets. Journal of Agricultural and Food Chemistry, Washington, v. 51, n. 19, p. 5780-5785, 2003.

LIU, S. et al. Fruit and vegetable intake and risk of cardiovascular disease: the women's health study. The American Journal of Clinical Nutrition, v. 72, n. 4, p. 922-928, Oct. 2000.

LUZ, P. L. da; CESENA, F. H. Y. Prevenção da doença coronariana. Revista da Sociedade de Cardiologia do Estado de São Paulo, v. 11, n. 2, p.7-20, 2001.

MAGALHÃES, C. C.; CHAGAS, A. C. P.; LUZ, P. L. da. Importância do HDL-colesterol como preditor de risco para eventos cardiovasculares. Revista da Sociedade de Cardiologia do Estado de São Paulo, v. 12 , n. 4 , p. $560-568,2002$.

MARCIL, V. et al. Modulation of lipid síntesis, apolipoprotein biogenesis, and lipoprotein assembly by butyrate. American Journal of Physiology: Gastrointestinal and Liver Physiology, v. 283, p. G340-G346, 2002.

MARLETT, J. A.; MCBURNEY, M. I.; SLAVIN, J. L. Health implications of dietary fiber. Journal of the American Dietetic Association, v. 102, n. 7, p. 993-1000, 2002.

MAZUR, W. M. et al. Isoflavonoids and lignans in legumes: nutritional and health aspects in humans. The Journal of Nutritional Biochemistry, v. 9, n. 4, p. 193-200, 1998.

OGINO, Y. et al. Absorption of Dietary Cholesterol Oxidation Products and Their Downstream Metabolic Effects are reduced by Dietary Apple polyphenols. Lipids, v. 42, p. 151-161, 2007.

PANAGIOTAKOS, D. B. et al. Consumption of fruits and vegetables in relation to the risk of developing acute coronary syndromes: the CARDIO2000 case-control study. Nutrition Journal, v. 2, 2003.
Disponível em: $<$ http://www.nutritionj.com/content/2/1/2>. Acesso em: 14 nov. 2003.

PETRI, J. L. Maçã. Disponível em: <petri@epagri.rct-sc.br>. Acesso em: 16 jul. 2003.

PHILIPPI, S. T. Tabela de composição de alimentos: suporte para decisão nutricional. Brasília: ANVISA/FINATEC/UNB, NUT, 2001. $133 \mathrm{p}$.

PLAAMI, S. P. Content of dietary fiber in foods and its physiological effects. Food Reviews International, v. 13, n. 1, p. 29-76, 1997.

PREgNOlatTO, W.; PREGNOLATTO, N. P. (Coord.). Normas analíticas do Instituto Adolfo Lutz. 3. ed. São Paulo: Instituto Adolfo Lutz, 1985. 578 p.

PRICE, M. L.; SCOYOC, S. V.; BUTLER, L. G. A critical evaluation of the vanillin reaction as an assay for tannin in sorghum grain. Journal of Agricultural Food Chemistry, Washington, v. 26, n. 5, p. 1214-1218, 1978.

REEVES, P. G.; NIELSEN, F. H.; FAHEY, G. C. AIN-93: purified diets for laboratory rodents: final report of the american institute of nutrition ad hoc writing committee on the reformulation of the AIN-76A Rodent Diet. The Journal of Nutrition, v. 123, n. 11, p. 1939-1951, 1993.

ROSS, R. Patogênese da aterosclerose. In: BRAUNWALD, E. (Ed.). Tratado de medicina cardiovascular. 5. ed. São Paulo: Roca, 1999. cap. 14, p. 1179-1198.

SABLE-AMPLIS, R.; SICART, R.; BLUTHE, E. Decreased cholesterol ester levels in tissues of hamsters fed with apple fiber enriched diet. Nutr. Rep. Int., v. 27, p. 881-889, 1983.

SANTOS, R. D. (Coord.). III Diretrizes brasileiras sobre dislipidemias e diretriz de prevenção da aterosclerose do Departamento de Aterosclerose da Sociedade Brasileira de Cardiologia. Arquivos Brasileiros de Cardiologia, Rio de Janeiro, v. 77, n. 3, p. 1-48, nov. 2001. Suplemento, 3.

SARRUGE, J. R.; HAAG, H. P. Análises químicas em plantas. Piracicaba: ESALQ-USP, 1974. 56 p.

SAVAIANO, D. A. Cardiovascular disease and fiber: is insulin resistance the missing link? Nutrition Reviews, v. 58 , n. 11, p. 356-358, 2000.

SEMBRIES, S. et al. Physiological Effects of Extraction Juices from Apple, Grape and Red Beet pomaces in Rats. Journal of Agricultural and Chemistry, Washington v. 54, n. 26, p. 10269-10280, 2006.

SWAIN, T.; HILLIS, W. E. The phenolic constituents of Prunus domestica I. The quantitative analysis of phenolic constituents. Journal of Science Food Agricultural, v. 10, p. 63-68, Jan. 1959.

VIDAL, R. et al. Apple procyanidins decrease cholesterol esterification and lipoprotein secretion in Caco - 2/TC7 enterocytes. Journal of Lipid Research, v. 46, n. 2, p. 258-268, 2005.

WILSKA-JESZKA, J. Proanthocyanidins: content in fruits and influence on health. Food Chemistry, v. 57, n. 1, p. 57-59, 1996. (Resumo).

WOLFE, K.; LIU, R. H. Antioxidant activity of apple peels. Journal of Agricultural and Food Chemistry, United States, v. 51, n. 3, p. 609-614, 2003.

ZONTA, E. P.; MACHADO, A. A. Programa SANEST: sistema de análise estatística para computadores (software). Pelotas: UFPel, 1980. 